Doi: https://doi.org/10.24036/jep/vol4-iss1/405

\title{
Pengembangan Lembar Kerja Peserta Didik Fisika Berbasis Pendekatan Science, Technology, Engineering, and Mathematics untuk Meningkatkan Berpikir Kritis Peserta Didik
}

\author{
Ramli Ramli*, Yohandri, Yulis Septianas Sari, Mitri Selisne \\ Jurusan Fisika, Universitas Negeri Padang, Jl. Prof Hamka, Padang 25131, Indonesia \\ *ramli@fmipa.unp.ac.id
}

\begin{abstract}
At present, education is directed towards forming students who have the competence of the industrial revolution 4.0, one of which has critical thinking skills. This article reports the results of research in developing a Physics student worksheet (LKPD) with the STEM (Science, Technology, Engineering, and Mathematics) approach, which is valid, practical and effective for enhancing students' critical thinking. Research and development $(R \& D)$ with the Borg \& Gall model has been used in this study, where the stages are initial research and information gathering, planning, developing initial product formats, and initial trials of products. The object of research is the Physics student worksheet based on the STEM approach. Data were collected using validation sheets, practicality test sheets and effectiveness test sheets. The effectiveness of the product was tested using a critical thinking ability test and an observation sheet of students' critical thinking processes. Data analysis uses analysis techniques for the validity, practicality and effectiveness of LKPD. The research results obtained are; firstly, the validity of the Physics student worksheet based on the STEM approach is 0.88 and this value is included in the valid category. Secondly, the practicality for the use of Physics student worksheets by teachers and students respectively 91.44 and 84.14. This value shows the Physics student worksheet is very practical. Besides that, the use of a Physics student worksheet based on the STEM approach is effective to enhance students' critical thinking.
\end{abstract}

Keywords : Berpikir kritis; LKPD; Peserta didik; STEM;

This is an open access article distributed under the Creative Commons 4.0 Attribution License, which permits unrestricted use, distribution, and reproduction in any medium, provided the original work is properly cited. $\odot 2020$ by author and Universitas Negeri Padang.

\section{PENDAHULUAN}

Saat ini, dunia telah memasuki era revolusi industri keempat atau industry 4.0. Karakteristik dari revolusi industri keempat ini adalah digitalisasi, optimasi dan kustomisasi produksi, otomasi dan adaptasi, interaksi manusia dengan mesin, layanan dan bisnis bernilai tambah, pertukaran data otomatis dan komunikasi, serta menggunakan teknologi informasi.

Dunia pendidikan telah dipengaruhi oleh perkembangan pesat teknologi era revolusi industri 4.0. ini. Dimana, dalam era industri 4.0. pembelajaran perlu menggunakan suatu pende katan yang dapat menjadikan peserta didik mempunyai kemampuan berpikir kritis, kreatif, inovatif, komunikatif, serta kolaboratif. Pening katan kualitas pendidikan di Indonesia perlu direformasi agar dapat menghadapi tantangan di era industry 4.0 yang memfokuskan pada komponen berpikir kritis peserta didik. Redhana (2010:142) mengatakan reformasi pendidikan dapat berupa perubahan pembelajaran tradisio nal kepada pembelajaran untuk meningkatkan berpikir kritis peserta didik.

Sumber daya manusia (SDM) yang berkualitas dan memiliki kompetensi dapat dihasilkan dari kurikulum yang diterapkan. Penerapan kurikulum 2013 ditandai dengan adanya model, pendekatan, strategi, metode, serta teknik dan taktik pembelajaran yang inovatif sehingga akan menghasilkan peserta didik yang diharapkan.

Menurut Muhadjir Effendy (Republika, 2018) perlu merevisi kurikulum bidang pendidi kan dengan menambahkan lima kompetensi yang diperlukan pada era revolusi industri 4.0, yaitu peserta didik diharapkan memiliki: 1) kemampuan berpikir kritis, 2) kreatifitas dan kemampuan yang inovatif, 3) kemampuan dan keterampilan berkomunikasi 4) bekerjasama dan berkolaborasi, 5) kepercayaan diri.

Menjawab tantangan revolusi industri 4.0 dan tuntutan kurikulum 2013, dalam pembela jaran perlu digunakan suatu pendekatan yang bisa menghasilkan sumber daya manusia yang diinginkan. Salah satunya adalah menggunakan 
pendekatan Science, Technology, Engineering, and Mathematics (STEM) dalam pembelajaran.

Pendidikan berbasis STEM dapat membentuk peserta didik memiliki kemampuan bernalar dan berpikir kritis, logis, dan sistematis. Nantinya, diharapkan peserta didik akan mampu menyongsong tantangan global dan tentunya akan meningkatkan perekonomian negara.

Pembelajaran STEM merupakan pembaur an pelajaran sains, teknologi, teknik, dan mate matika. Terkait dengan lingkungan, pendekatan STEM mewujudkan suatu pembelajaran dengan menghadirkan dunia nyata kehidupan sehari-hari yang dialami oleh peserta didik.

STEM dapat diimplementasikan pada mata pelajaran Fisika. Fisika adalah bagian dari sains merupakan ilmu yang mempelajari gejala alam, tidak hanya sebagai pengetahuan tapi lebih kepada implementasi dan peranannya terhadap kehidupan manusia. Hal ini sejalan dengan teori STEM, yaitu melalui pendekatan STEM peserta didik tidak hanya menghapalkan saja, namun paham dan mengerti konsep sains serta menghubungkannya di kehidupan seharihari.

Pembelajaran Fisika diharapkan dilaksa nakan sesuai dengan tuntutan Kurikulum 2013. Namun kenyataan di lapangan, pembelajaran Fisika belum sesuai dengan tuntutan kurikulum. Hal ini terungkap berdasarkan data awal yang diambil menggunakan lembar wawancara. Aspek-aspek yang ditanyakan pada lembar wawancara yaitu: pembelajaran fisika, penggunaan bahan ajar fisika, penggunaan LKPD, pendekatan dan metode pembelajaran, evaluasi dan berpikir kritis siswa.

Pengambilan data awal dilakukan di tiga sekolah yaitu SMAN 2 Padang, SMAN 7 Padang, dan SMAN 13 Padang. Berdasarkan wawancara yang telah dilakukan terlihat bahwa pelaksanaan pembelajaran Fisika di sekolah belum dilaksanakan secara optimal. Adapun yang menjadi faktor penyebabnya adalah pembe lajaran masih berpusat pada guru sehingga berpikir kritis peserta didik kurang terlatihkan. Konsekuensinya, peserta didik akan kesulitan memecahkan masalah yang mereka hadapi secara kritis. Disamping itu, metode ceramah masih sering digunakan guru dalam pembela jaran, dan peserta didik masih kurang termotivasi untuk mempelajari Fisika.

Kemampuan berpikir kritis peserta didik masih kurang yang terlihat dari tidak terpenuhinya semua indikator berpikir kritis yaitu: 1) memberikan klarifikasi dasar terhadap permasalahan, 2) mengumpulkan informasi dasar, 3) memberikan pendapat dan kesimpulan awal, 4) membuat klarifikasi lebih lanjut, dan 5) menarik kesimpulan yang terbaik.

Berdasarkan data awal ditemukan bahwa peserta didik telah menggunakan LKPD yang merupakan lembaran yang disiapkan oleh guru sebagai bahan belajar baik secara kelompok maupun secara individu. Khusus untuk kegiatan eksperimen, LKPD berisikan konsep materi, tugas dan langkah-langkah pelaksanaan perco baan, yang berfungsi sebagai pedoman bagi peserta didik melakukan eksperimen.

Namun, LKPD yang digunakan oleh peserta didik di sekolah masih belum sesuai dengan harapan. Beberapa kekurangan yang ditemukan diantaranya: struktur LKPD yang belum lengkap yang mana kompetensi yang akan dicapai belum tergambar dengan jelas, tidak terdapat pentunjuk penggunaan LKPD. Idealnya menurut Depdiknas (2008) LKPD berisi; judul, petunjuk belajar, kompetensi, informasi pendukung, tugas dan langkah kerja, dan penilaian. Temuan awal selanjutnya menda pat perhatian adalah LKPD belum memuat pendekatan STEM.

Bertitik tolak dari kondisi yang diharapkan dengan kondisi nyata di lapangan ditemukan adanya kesenjangan. Pada kenyata annya pelaksanaan pembelajaran Fisika belum diterapkan dengan baik menurut tuntunan kurikulum 2013 yang mana peserta didik harus mempunyai lima kompetensi, diantaranya adalah kemampuan berpikir kritis.

Untuk mengatasi hal ini dalam pembela jaran perlu diterapkan suatu pendekatan sesuai tuntutan Kurikulum 2013 yaitu pendekatan STEM. Pendekatan STEM merupakan pende katan pembelajaran yang dapat melatihkan keterampilan berpikir kritis pada peserta didik.

Dari berbagai masalah yang ditemukan di lapangan, ada beberapa solusi yang bisa dilakukan guru membantu memecahkan masalah tersebut. Salah satunya adalah dengan membuat LKPD Fisika berbasis pendekatan STEM. STEM pertama kali diluncurkan di Amerika Serikat tahun 1990-an untuk menumbuhkan angkatan kerja di bidang STEM, mengem bangkan melek STEM bagi warga negara, serta meningkatkan daya saing global dalam inovasi IPTEK (Rustaman, 2016).

Berdasarkan pemaparan tersebut, pembelajaran menggunakan pendekatan STEM 
sangatlah penting, untuk memberi kepada peserta didik agar dapat mengintegrasikan masing-masing bidang STEM. Konsekuensinya, penerapan pendekatan STEM diharapkan dapat membekali peserta didik dengan keterampilanketerampilan yang diperlukan untuk mengha dapi persaingan di era industri 4.0.

Selain pendekatan pembelajaran, penggu naan bahan ajar yang tepat diperlukan agar keterampilan peserta didik yang diharapkan di era industri 4.0 tercapai, misalnya keterampilan berpikir kritis peserta didik dapat terlatih. LKPD sebagai salah satu bahan ajar memainkan peran penting dalam melatihkan kemampuan berpikir kritis peserta didik. Oleh karena itu, perlu dikembangkan LKPD Fisika berbasis STEM untuk meningkatkan kemampuan berpikir kritis peserta didik.

Pendidikan STEM telah digunakan pada beberapa negara maju seperti Amerika Serikat, Jepang, Finlandia, Australia dan Singapura (Han dkk, 2014). Sementara di Indonesia beberapa penelitian tentang pembelajaran berbasis STEM telah dilaporkan oleh beberapa peneliti (Ismayani, 2016; Ismail dkk, 2016; Afriana dkk, 2016; Sukmana, 2017; Dewi dkk, 2018). Namun demikian, untuk menunjang pelaksanaan pembe lajaran tentulah diperlukan bahan ajar berbasis STEM, salah satunya LKPD.

Perancangan LKPD dalam penelitian ini berdasarkan tahap analisis pada penelitian pendahuluan yang dilakukan. Tahap awal dalam pengembangan produk yaitu peneliti mengiden tifikasi masalah, penyebab masalah serta kemungkinan solusi yang dapat diambil untuk menyelesaikan masalah tersebut. Borg \& Gall (1989) menyatakan bahwa tahap pertama penelitian pengembangan yaitu dimulai dari pengumpulan informasi awal yang meliputi analisis kebutuhan, studi kepustakaan, dan ketersediaan SDM yang kompeten. Untuk itu tahapan yang dilakukan untuk mengumpulkan informasi awal, diantaranya analisis kebutuhan, analisis peserta didik, analisis materi, serta analisis tugas.

Di Indonesia, Pendidikan STEM telah merujuk pada empat bidang ilmu (sains, teknologi, teknik, dan matematika). Pendidikan STEM bertujuan agar peserta didik mampu mengembangkan kompetensi yang telah dimi likinya dan menerapkannya dalam pelbagai situasi dan masalah yang dihadapi sehari-hari (Mayasari dkk, 2014). Pendidikan STEM sejalan dengan keterampilan abad 21, yakni; creativity, critical thinking, collaboration, dan commu nication (Beer, 2011).

Dalam penelitian ini, pendekatan STEM diintegrasikan dalam LKPD, yang dikembang kan untuk melatih kemampuan berpikir kritis peserta didik, dimana penyusunan LKPD mengacu pada Depdiknas (2008). Tentunya, setelah menggunakan LKD, terjadi peningkatan kemampuan berpikir kritis peserta didik. Kemampuan berpikir kritis ini sangat diperlukan untuk menganalisis suatu masalah sampai pada tahap mencari solusi dalam menyelesaikan masalah tersebut.

Berdasarkan latar belakang yang diungkapkan, peneliti tertarik mengembangkan LKPD Fisika berbasis pendekatan STEM untuk meningkatkan kemampuan berpikir kritis peserta didik di Sekolah Menengah Atas (SMA). Melalui LKPD ini peserta didik menjadi aktif dan mempunyai ketertarikan pada materi yang dibahas. Keuntungan dari pengembangan LKPD ini adalah peserta didik memahami materi Fisika dan memiliki kemampuan berpikir kritis, dan adanya LKPD Fisika yang representif yang menghubungkan antara pembelajaran dengan permasalahan dunia nyata.

\section{METODE PENELITIAN}

Jenis penelitian yang digunakan yaitu penelitian dan pengembangan dengan model Borg and Gall. Borg and Gall (dalam Sugiyono, 2012:9) menyatakan penelitian dan pengem bangan adalah suatu metode penelitian yang digunakan dalam mengembangkan atau memvalidasi produk di bidang pendidikan. Disamping itu, metode penelitian ini juga digunakan untuk membuat produk tertentu, serta menguji efektifitas produk (Sugiyono, 2012).

Penelitian ini menghasilkan produk LKPD Fisika berbasis pendekatan STEM. LKPD Fisika yang dihasilkan diuji validitasnya, kepraktisannya serta keefektifannya sehingga menjadi bahan ajar yang berkualitas.

Langkah-langkah pengembangan menga cu pada sepuluh langkah menurut Borg \& Gall (Sukmadinata,2009). Peneliti melakukan penye derhanaan tahapan dari kesepuluh langkah tersebut, menjadi empat langkah. Penyederha naan ini berdasarkan pendapat Borg \& Gall dalam Emzir (2010) yang menyarankan untuk membatasi penelitian dalam skala kecil, termasuk kemungkinan untuk membatasi langkah-langkah penelitian. Empat langkah tersebut adalah; penelitian dan pengumpulan 
data, perencanaan, pengembangan draf produk awal, dan uji coba lapangan awal.

Secara umum, pengumpulan data terdiri dari 3 instrumen yakni: instrumen uji validitas LKPD oleh tenaga ahli menggunakan lembar validasi tenaga ahli, instrumen uji kepraktisan tentang keterlaksanaan dan kemudahan pene rapan LKPD menggunakan lembar uji keprak tisan guru dan peserta didik, serta instrumen efektivitas penggunaan LKPD melalui pretest dan posttest dan lembar observasi berpikir kritis.

Analisis validitas menggunakan Skala Likert dan dianalisis menggunakan rumus Aiken's V dalam Persamaan (1):

$$
V=\frac{\sum s}{[n(c-1)]}
$$

dengan:

$s=r-l o$

$l o=$ skor validitas terendah (dalam hal ini $=1)$

$c=$ skor validitas tertinggi (dalam hal ini $=4)$

$r=$ Skor dari validator

Rumus yang digunakan untuk menghitung nilai akhir praktikalitas (dalam skala 0-100) dinyata kan dalam Persamaan (3).

$$
\text { Nilai Akhir }=\frac{\text { perolehan skor }}{\text { skor maksimum }} \times 100
$$

Data kemampuan berpikir kritis diukur dari skor tes sebelum (pretest) dan sesudah (posttest) menggunakan LKPD. Data tersebut dianalisis menggunakan analisis $N$-Gain yang diadaptasi dari Hake (1998) seperti dalam Persamaan (4).

$$
\langle g\rangle=\frac{\%<s_{\text {post }}>-\%<s_{\text {pre }}>}{100-\%<s_{\text {pre }}>}
$$

dengan:

$\langle g\rangle \quad: N$-Gain score (rata-rata)

$\left\langle s_{\text {pre }}\right\rangle$ : Rata-rata pretest

$<s_{\text {post }}>$ : Rata-rata posttest

Sementara itu, aktivitas peserta didik dalam berpikir kritis dianalisis menggunakan Persamaan (5).

$$
J=\frac{K}{L} 100 \%
$$

dengan:

$$
\begin{aligned}
& K=\text { Jumlah frekuensi } \\
& L=\text { Total jumlah frekuensi } \\
& J=\text { Persentase aktivitas peserta didik }
\end{aligned}
$$

\section{HASIL DAN PEMBAHASAN}

Telah dilakukan analisis kebutuhan dalam rangka pengembangan LKPD Fisika berbasis pendekatan STEM pada beberapa SMA di kota Padang. Analisis kebutuhan ini teridiri dari: 1) analisis performa, 2) analisis standar kelulusan, dan 3) analisis kesulitan belajar peserta didik.

Berdasarkan analisis performa diperoleh nilai rata-rata $69,5 \%$. Nilai ini berada pada kategori cukup. Namun ada beberapa sub indikator pada indikator identifikasi guru yang memiliki nilai persentase rendah dan perlu ditingkatkan. Sub indikator tersebut diantaranya penggunaan LKPD dalam pembelajaran, desain LKPD, dan penggunaan pendekatan pada proses pembelajaran dengan nilai $58,33 \%$ yang berada pada kategori kurang.

Berdasarkan analisis standar kelulusan diperoleh bahwa aspek pengetahuan peserta didik dengan kategori kurang (persentase nilai rata-rata 58,33\%). Selanjutnya, untuk aspek keterampilan juga dengan kategori kurang (per sentase nilai rata-rata 58,33\%). Ini menandakan peserta didik memiliki kemampuan dan keterampilan ilmiah masih kurang.

Sementara itu, hasil analisis kesulitan belajar peserta didik diperoleh nilai rata-rata $60,37 \%$ dengan kategori cukup. Namun ada beberapa indikator pada analisis kesulitan belajar yang memiliki nilai persentase rendah. Indikator tersebut diantaranya LKPD yang tersedia di sekolah yang kurang memudahkan peserta didik dalam proses pembelajaran dengan nilai 60,00\% (kategori kurang). Kemudian, pendekatan yang digunakan guru untuk melatih kemampuan berpikir kritis peserta didik dengan nilai 58,33\% (kategori kurang). Berikutnya, kemampuan berpikir kritis peserta didik diperoleh nilai 60,00\% (kategori kurang). Ketiga indikator dalam analisis kesulitan belajar ini perlu ditingkatkan untuk menunjang pembe lajaran yang sesuai tuntutan Kurikulum 2013. Hasil-hasil analisis kebutuhan di atas ditindak lanjuti dengan mengembangan LKPD Fisika berbasis pendekatan STEM.

Berdasarkan analisis data pada tahap pengembangan produk, diperoleh validitas LKPD Fisika berbasis pendekatan STEM. Peni laian validitas LKPD dilakukan oleh tiga orang dosen Fisika. Uji validitas LKPD dilakukan sete lah uji validitas instrumen dilakukan. Hasil uji validitas LKPD diperoleh setelah menganalisis data lembar validitas oleh tiga orang ahli 
menggunakan statistik Aiken's $V$. Hasil validitas LKPD diperlihatkan dalam Tabel 1.

Tabel 1. Nilai Validitas LKPD

\begin{tabular}{clcc}
\hline No. & \multicolumn{1}{c}{ Aspek } & Nilai $\boldsymbol{V}$ & Kategori \\
\hline 1. & Kelayakan Isi & 0,88 & Valid \\
2. & Kelayakan & 0,90 & Valid \\
& $\begin{array}{l}\text { Penyajian } \\
\text { 3. }\end{array}$ & & \\
Kelayakan Bahasa & 0,85 & Valid \\
& $\begin{array}{l}\text { Kelayakan } \\
\text { Kegrafikan }\end{array}$ & 0,89 & Valid \\
& Rata-rata & 0,88 & Valid \\
\hline
\end{tabular}

Tabel 1 memperlihatkan nilai setiap komponen pada penilaian validasi LKPD memiliki rentangan nilai $V 0,85$ sampai 0,90 . Secara keseluruhan setiap komponen dengan kategori valid. Selanjutnya diperoleh nilai ratarata validasi LKPD adalah 0,88. Dengan demikian LKPD Fisika dengan menggunakan pendekatan STEM adalah valid. Jadi, LKPD ini valid digunakan dalam proses pembelajaran.

Setelah melakukan ujicoba lapangan awal diperoleh praktikalitas LKPD. Hasil uji kepraktisan menurut guru diperoleh dari analisis terhadap instrumen lembar uji kepraktisan menurut guru. Sebanyak dua orang guru Fisika SMAN 2 Padang menilai kepraktisan LKPD, hasilnya diperlihatkan dalam Gambar 1. Instru men lembar uji kepraktisan menurut guru ada empat komponen, yakni: 1) kepraktisan, 2) kemudahan, 3) keterlaksanaan, dan 4) keefek tifan waktu penggunaan LKPD.

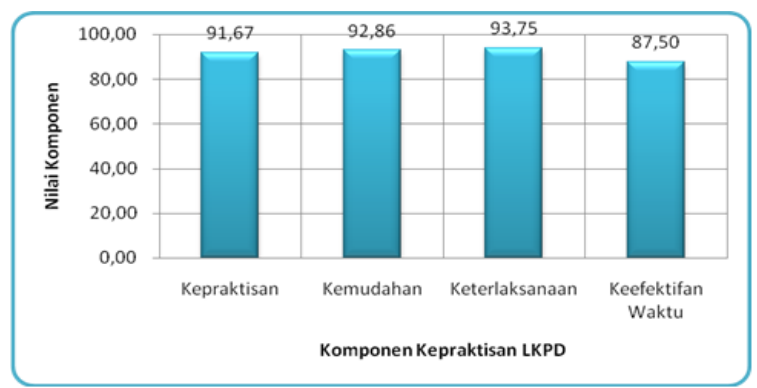

Gambar 1. Nilai Rata-Rata Kepraktisan LKPD Menurut Guru.

Gambar 1, memperlihatkan bahwa secara keseluruhan nilai komponen berada pada kategori sangat praktis. Nilai rata-rata penilaian kepraktisan LKPD menurut guru adalah 91,40. Oleh karena itu LKPD Fisika berbasis pendekatan STEM sangat praktis digunakan untuk meningkatkan berpikir kritis dari peserta didik. Hal ini terjadi karena di dalam LKPD memuat indikator-indikator berpikir kritis yang dilatihkan kepada peserta didik selama pembelajaran menggunakan LKPD.
Selanjutnya, uji kepraktisan menurut peserta didik dianalisis berdasarkan angket peserta didik dalam penggunaan LKPD Fisika berbasis pendekatan STEM. Pada instrumen kepraktisan menurut peserta didik terdapat tiga komponen. Komponen tersebut adalah kemudahan, kepraktisan, dan daya tarik. Setiap komponen terdiri dari beberapa indikator. Peserta didik dapat memberikan bobot pada setiap indikator dari rentangan 1 sampai 4 . Jumlah peserta didik yang mengisi angket adalah 35 orang. Berdasarkan rata-rata setiap komponen dapat ditentukan nilai rata-rata kepraktisan penggunaan LKPD menurut peserta didik. Hasil plot data nilai setiap komponen diperlihatkan dalam Gambar 2.

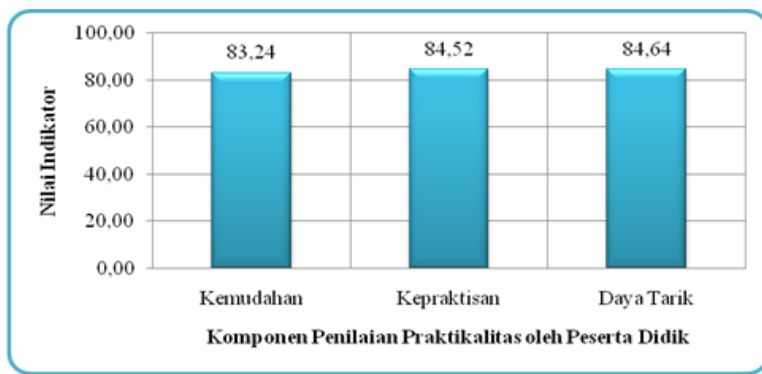

Gambar 2. Nilai Rata-Rata Kepraktisan LKPD Menurut Peserta Didik

Gambar 2 menjelaskan nilai kepraktisan LKPD menurut peserta didik sebagai pengguna LKPD dalam kegiatan pembelajaran. Terlihat dalam Gambar 2 nilai rata-rata dari semua komponen adalah 84,14 dengan kategori sangat praktis. LKPD Fisika berbasis pendekatan STEM adalah sangat praktis digunakan.

Penilaian aktivitas berpikir kritis peserta didik dilakukan oleh guru selama proses pembelajaran dikelas. Pada instrumen penilaian terdapat dua belas indikator penilaian berpikir kritis, yaitu: 1) memfokuskan pertanyaan, 2) menganalisis argumen, 3) bertanya dan menja wab pertanyaan, 4) mempertimbangkan apakah sumber dapat dipercaya atau tidak, 5) menga mati dan mempertimbangkan hasil yang diamati, 6) membuat deduksi dan mempertimbangkan hasil deduksi, 7) membuat induksi dan memper timbangkan hasil induksi, 8) membuat dan menentukan nilai pertimbangan, 9) mengiden tifikasi istilah dan mempertimbangkan suatu definisi, 10) mengidentifikasi asumsi-asumsi, 11) memutuskan suatu tindakan, dan 12) berin teraksi dengan orang lain. Nilai rata-rata aktivitas berpikir kritis dari peserta didik adalah 79,86 untuk pertemuan ke-1, 82,18 untuk pertemuan ke-2 dan 85,42 pada pertemuan ke-3. 
Sementara kemampuan berpikir kritis peserta didik dinilai berdasarkan hasil pretest dan posttest. Hasil uji pretest dan posttest peserta didik dalam penggunaan LKPD diperlihatkan pada Tabel 2.

Tabel 2. Data Perhitungan Pretest dan Posttest

\begin{tabular}{clccc}
\hline No. & $\begin{array}{c}\text { Parameter } \\
\text { Statistik }\end{array}$ & \multicolumn{2}{c}{ Pretest Posttest } & Gain \\
\hline 1. & Nilai Rata-rata & 51,17 & 78,92 & \\
2. & Varians & 44,89 & 87,79 & \\
3. & Standar Deviasi & 6,70 & 9,37 & \\
4. & Nilai Terendah & 43 & 47 & 0,57 \\
5. & Nilai Tertinggi & 65 & 90 & 0,57 \\
6. & Median & 50 & 81,5 & \\
7. & Modus & 55 & 86 & \\
8. & Rentangan Nilai & 22 & 43 & \\
\hline
\end{tabular}

Tabel 2 memperlihatkan bahwa kemam puan berpikir kritis dari peserta didik meningkat setelah menggunakan LKPD, yaitu dengan nilai rata-rata 51,17 menjadi 78,92 . Apabila dilihat antara standar deviasi pretest dan posttest terjadi penurunan. Penurunan pada standar deviasi menyatakan bahwa kenaikan nilai peserta didik tidak hanya terjadi pada beberapa orang saja, namun juga diikuti hampir semua peserta didik.

Berdasarkan analisis gain score pada Persamaan (4), dapat dinyatakan bahwa adanya peningkatan rata-rata kemampuan berpikir kritis peserta didik. Hal ini dilihat dari hasil peningkatan gain score sebesar 0,57 dengan kate gori sedang. Dengan demikian, LKPD Fisika berbasis pendekatan STEM ini dapat meningkat kan kemampuan berpikir kritis dari peserta didik. Temuan ini menyatakan bahwa LKPD yang dikembangkan efektif digunakan pada pembelajaran untuk meningkatkan kemapuan berpikir kritis peserta didik.

Hasil penelitian di atas menjelaskan karakteristik dari LKPD yang telah dibuat, hasil validasi oleh tenaga ahli, hasil uji kepraktisan menurut guru dan peserta didik, serta hasil uji efektivitas penggunaan LKPD Fisika berbasis pendekatan STEM. Hasil penelitian menunjuk kan adanya kecocokan antara hasil yang didapat dengan kajian teori.

Hasil penelitian ini mengungkapkan karakteristik LKPD yang dibuat sesuai dengan hasil analisis kebutuhan, serta dirancang berda sarkan struktur penulisan LKPD menurut Depdiknas (2008). Rancangan dari LKPD dapat dijelaskan sebagai berikut. Pertama sampul LKPD dirancang sedemikian rupa agar LKPD terlihat menarik. Kedua, materi dalam LKPD telah sesuai dengan kompetensi inti, kompetensi dasar, dan indikator yang telah ditetapkan diperinci lagi menjadi tujuan instruksional yang harus dicapai setelah pembelajaran. Ketiga, di dalam LKPD ini disediakan petunjuk belajar untuk peserta didik dan guru untuk dapat menggunakan LKPD ini secara mandiri. Keempat, LKPD dilengkapi dengan informasi pendukung yang merupakan uraian ringkas materi dalam bentuk penjelasan konsep dan fenomena kehidupan sehari-hari yang memuat komponen pendekatan STEM. Kelima, tugastugas dan langkah kerja pada LKPD juga memuat pendekatan STEM. Pada langkah kerja, peserta didik dituntut untuk mengerjakan tugastugas yang dapat mengembangkan kompeten sinya. Keenam, LKPD menyediakan penilaian bagi peserta didik dimana soal yang diberikan relevan dengan materi pada LKPD tersebut.

Validasi LKPD Fisika berbasis pende katan STEM dilakukan oleh tiga orang tenaga ahli yang merupakan dosen Fisika FMIPA Universitas Negeri Padang. Berdasarkan hasil analisis terhadap lembar validasi tenaga ahli didapatkan nilai rata-rata gain sebesar 0,88. Hasil ini meng identifikasi bahwa LKPD Fisika berbasis pendekatan STEM berada pada kategori valid. LKPD berbasis pendekatan STEM valid pada aspek kelayakan; isi, penyajian, bahasa, dan kegrafisan. Pertama, valid pada aspek kelayakan isi karena LKPD ini disusun sesuai dengan KD dan indikator materi Fisika kelas XI semester 2, gambar dan contoh yang diberikan sesuai dengan kehidupan sehari-hari, dan LKPD memuat pendekatan STEM yang bisa melatih kemampuan berpikir kritis dari peserta didik. Kedua, valid pada aspek kelayakan penyajian karena LKPD yang dibuat mengacu pada sistematika penulisan sesuai Depdiknas (2008). Ketiga, valid pada aspek bahasa karena LKPD yang dibuat sudah menggunakan bahasa dan ejaan yang sesuai EYD. Keempat, valid pada aspek kelayakan kegrafisan karena LKPD bisa membuat peserta didik agar tidak bosan dalam menggunakan LKPD. Hal ini disebabkan karena LKPD yang dibuat menarik, baik dalam hal penataan cover, warna, dan huruf yang digu nakan. Kategori valid berada pada nilai $\geq 0,6$.

Disisi lain, belum semua komponen pada lembar validasi mencapai kesempurnaan. Revisi yang dilakukan antara lain terdapat pada petunjuk guru, sesuaikan indikator dan tujuan pembelajaran dengan $\mathrm{KD}$, penulisan kalimat pada LKPD, pilihan soal pada LKPD, dan 
gambar pada percobaan. Setelah melakukan revisi dapat dikatakan bahwa produk LKPD Fisika berbasis pendekatan STEM memiliki deskripsi yang baik sebagai salah satu bahan ajar. Hal ini disebabkan karena LKPD dirancang dan dibuat berdasarkan struktur LKPD serta perbaikan dilakukan berdasarkan saran-saran terhadap kekurangan-kekurangan yang terdapat pada LKPD Fisika berbasis pendekatan STEM.

Hasil yang dicapai untuk uji kepraktisan LKPD Fisika berbasis pendekatan STEM diperoleh dari dua kategori. Kategori tersebut meliputi uji kepraktisan menurut guru dan uji kepraktisan menurut peserta didik. Hasil analisis kepraktisan oleh guru dan peserta didik masing masing 91,44 dan 84,14 yang menyatakan bahwa ia berada dalam kategori sangat praktis.

LKPD yang telah dikembangkan praktis pada aspek kepraktisan, kemudahan, keterlak sanaan, keefektifan waktu, dan daya tarik. Pertama, praktis pada aspek kepraktisan karena LKPD praktis dibawa kemana saja oleh peserta didik. Kedua, praktis pada aspek kemudahan karena LKPD menyajikan materi dengan komponen-komponen yang jelas sehingga peserta didik mudah membaca dan mema haminya. Ketiga, praktis pada aspek keterlak sanaan karena komponen pendekatan STEM dapat dilaksanakan dengan baik sehingga dapat mengasah keterampilan berpikir kritis peserta didik. Keempat, praktis pada aspek keefektifan waktu karena LKPD dapat digunakan sesuai alokasi waktu pembelajaran. Kelima, praktis pada aspek daya tarik karena LKPD menyajikan tampilan yang menarik, sehingga peserta didik termotivasi dan semangat belajar menggunakan LKPD Fisika Berbasis Pendekatan STEM ini. Hal ini membuktikan bahwa LKPD Fisika berbasis pendekatan STEM praktis digunakan baik oleh guru maupun peserta didik SMA kelas XI dalam pembelajaran untuk meningkatkan berpikir kritis dari peserta didik. Sejalan dengan hal ini, penelitian yang telah dilakukan oleh Khoiriyah (2018) menyimpulkan bahwa penerapan pendekatan STEM mampu mening katkan kemampuan berpikir kritis siswa SMA pada materi ajar gelombang dan bunyi.

LKPD yang dihasilkan pada penelitian ini efektif meningkatkan berpikir kritis dari peserta didik dalam pembelajaran fisika. Hal ini sesuai dari hasil observasi aktivitas peserta didik dalam berpikir kritis dan penilaian kemampuan berpikir kritis dari peserta didik.
Aktivitas berpikir kritis dari peserta didik diamati mengalami peningkatan pada setiap pertemuan Sementara, berdasarkan analisis gain score diperoleh peningkatan rata-rata kemam puan berpikir kritis peserta didik setelah meng gunakan LKPD. Peserta didik dapat meman faatkan LKPD ini sesuai dengan materi pembelajaran yang ada pada LKPD dalam menambah pemahaman terhadap pembelajaran Fisika dan melatih kemampuan berpikir kritis.

Hasil penelitian yang dilaporkan ini sejalan dengan beberapa laporan peneliti lain. Penelitian Sari (2019) menyimpulkan bahwa pembelajaran Fisika menggunakan LKPD dengan pendekatan STEM efektif untuk meningkatkan kompetensi belajar peserta didik mencakup pengetahuan, sikap, dan keteram pilan. Sejalan dengan itu, penelitian Runco (2010), Farwati (2017), Kuenzi (2008) juga menyimpulkan bahwa bahan ajar yang menggunakan pendekatan STEM dapat meningkatkan kompetensi belajar peserta didik.

\section{KESIMPULAN}

Berdasarkan hasil penelitian yang telah dianalisis dapat dibuat kesimpulan. Pertama, LKPD menggunakan pendekatan STEM telah dihasil kan dengan karakteristik yaitu: penyajian LKPD menggunakan empat komponen pende katan STEM yaitu: Science, Technology, Enge neering, dan Mathematics. Kedua, LKPD Fisika berbasis pendekatan STEM mempunyai kriteria yang valid. Karakteristik kevalidan LKPD ter tuang dalam penyusunan draf komponen LKPD, valid dalam aspek kelayakan isi, penyajian, bahasa, dan kegrafikan. Ketiga, LKPD Fisika berbasis pendekatan STEM mempunyai kriteria yang praktis. karakteristik kepraktisan LKPD ini terdiri dari kemudahan, kepraktisan, dan daya tarik. Kepraktisan LKPD dirasakan oleh peserta didik yang berkemampuan rendah, sedang, dan tinggi. Keempat, LKPD Fisika berbasis pende katan STEM mempunyai kriteria yang efektif. Karakteristik keefektifan LKPD dapat mening katkan kemampuan berpikir kritis dari peserta didik dinilai dari hasil belajar peserta didik dan observasi berpikir kritis peserta didik selama proses pembelajaran.

\section{UCAPAN TERIMAKASIH}

Terimakasih diucapkan kepada DRPM Dikti yang telah membiayai penelitian dengan skema Penelitian Tesis Magister, nomor kontrak: 357/UN.35.13/LT/2019. 


\section{DAFTAR PUSTAKA}

Afriana, J., Permanasari, A., \& Fitriani, A. (2016). Penerapan Project Based Learning Terintegrasi STEM untuk Meningkatkan Literasi Sains Siswa Ditinjau dari Gender. Jurnal Inovasi Pendidikan IPA,2(2), 202212.

Beers, S. (2011). 21st Century Skills : Preparing Students for Their Future. Diambil dari: http://www.yinghuaacademy.org/wpcontent/ uploads/2014/10/21stcenturyskills.pdf

Borg, W.R., \& Gall, M.D. Gall. (1989). Educational Research: An Introduction, Fifth Edition. New York: Longman.

Depdiknas. 2008. Panduan Pengembangan Bahan Ajar. Jakarta: Depdiknas.

Dewi, M., Kaniawati, I., \& Suwarma, I.R. (2018), Penerapan Pembelajaran Fisika Menggunakan Pendekatan STEM untuk Meningkatkan Kemampuan Memecahkan Masalah Siswa pada Materi Listrik Dinamis, Seminar Nasional Quantum \#25. 381-385.

Emzir. (2010). Metodologi Penelitian Pendidikan : Kuantitatif dan Kualitatif. Depok: PT. Raja Grafindo Persada.

Farwati, R., Permanasari, A., Firman, H., \& Suhery, T. (2017). Integrasi Problem Based Learning dalam STEM Education Berorien tasi pada Aktualisasi Literasi Lingkungan dan Kreativitas. Prosiding Seminar Nasional Pendidikan IPA 2017. 198-206.

Hake, R.R. (1998). Interactive Engagement Versus Traditional Methods: A Sixthousand-student Survey of Mechanics Test Data for Introductory Physics Courses, American Journal of Physics. 66, 64-74.

Han, S., Capraro, R. \& Capraro, M. M. (2014). How Science, Technology, Engineering, and Mathematics (STEM) Project-Based Learning (PBL) Affects High, Middle, and Low Achievers Differently: The Impact of Student Factors on Achievement. International Journal of Science and Mathematics Education, 13(5). 1089-1113.

Ismail, I., Permanasari, A., \& Setiawan, W., (2016), Efektivitas Virtual Lab Berbasis STEM dalam Meningkatkan Literasi Sains Siswa dengan Perbedaan Gender, Jurnal Inovasi Pendidikan IPA, 2(2). 190 - 201.

Ismayani, A., (2016). Pengaruh Penerapan STEM Project-Based Learning Terhadap Kreativitas Matematis Siswa SMK, Indonesian Digital Journal of Mathematics and Education. 3(4). 264-272.

Khoiriyah, N,, Abdurrahman., \& Wahyudi, I., (2018). Implementasi Pendekatan Pembelajaran STEM untuk Meningkatkan
Kemampuan Berpikir Kritis Siswa SMA pada Materi Gelombang Bunyi. Jurnal Riset dan Kajian Pendidikan Fisika, 5(2). 53-62.

Kuenzi, J., (2008). Science, Technology, Engineering, and Mathematics (STEM) Education: Background, Federal Policy, and Legislative Action. Congressional Research Service Reports. 35. Diambil dari: https:// digitalcommons.unl.edu/crsdocs/35

Mayasari, T., Kadarohman, A., \& Rusdiana, D. (2014). Pengaruh Pembelajaran Terintegrasi Science, Technology, Engineering, And Mathematics (STEM) Pada Hasil Belajar Peserta Didik: Studi Meta Analisis. Prosiding Semnas Pensa VI. 371-377.

Redhana, I.W, (2010), Pengaruh Model Pembe lajaran Berbasis Peta Argumen Terhadap Keterampilan Berpikir Kritis Siswa pada Topik Laju Reaksi. Jurnal Pendidikan dan Pengajaran, 43(17). 141-148.

Republika, 2018. Mendikbud Ungkap Cara Hadapi Revolusi 4.0 di Pendidikan. Diambil dari: https://www.republika.co.id/berita/pen didikan/eduaction/18/05/02/p8388c430mendikbud-ungkap-cara-hadapi-revolusi-40di-pendidikan.

Runco, M.A., Millar,G., Acar, S. \& Gramond, B (2010). Torrance Tests of Creative Thinking as Predictors of Personal and Public Achieve ment: A Fifty-Year Follow-up. Creativity Research Journal, 22(4), 361-368.

Rustaman, N.Y. (2016). Pembelajaran Sains Masa Depan Berbasis STEM Education. Prosiding Seminar Nasional Biologi Edu kasi 2016. Universitas Pendidikan Indonesia

Sari, Y.S., Selisne, M., \& Ramli, R. (2019). Role of Students Worksheet in STEM Approach to Achieve Competence of Physics Learning. Journal of Physics: Conference Series. 1185. 012096.

Sugiyono. (2012). Metode Penelitian Kuantitatif, Kualitatif, dan $R \& D$. Bandung: Afabeta.

Sukmadinata, N. S. (2009). Metode Penelitian Pendidikan. Bandung: Rosda Karya.

Sukmana, R.W. (2017), Pendekatan Science, Technology, Engineering and Mathematics (STEM) Sebagai Alternatif dalam Mengembangkan Minat Belajar Peserta Didik Sekolah Dasar. Pendas: Jurnal Ilmiah Pendidikan Dasar, 2(2). 189 - 197. 